\title{
MORPHOGENESIS, STRUCTURE, AND DYNAMICS OF PAIAGUAS PALISADEGRASS TILLERING AFTER INTERCROPING WITH SORGHUM FOR THE RECOVERY OF PASTURE IN DIFFERENT FORAGE SYSTEMS
}

\author{
MORFOGENNESE, ESTRUTURA E DINÂMICA DO PERFILHAMENTO DO CAPIM- \\ PAIAGUÁS APÓS O CONSÓRCIO COM SORGO NA RECUPERAÇÃO DE \\ PASTAGEM EM DIFERENTES SISTEMAS FORRAGEIROS
}

\author{
Jessika Torres da Silva ${ }^{1}$; Kátia Aparecida de Pinho Costa ${ }^{1}$; Victor Costa e Silva ${ }^{1}$; \\ Wender Ferreira de Souza ${ }^{1}$; Daniel Augusto Alves Teixeira ${ }^{2}$; Eduardo da Costa Severiano ${ }^{1}$ \\ 1. Instituto Federal Goiano, Campus Rio Verde, Rio Verde, GO, Brasil. katia.costa@ifgoiano.edu.br. \\ 2. Universidade Federal do Goiás, Goiânia, Goiás, Brasil.
}

\begin{abstract}
The use of pasture is the most economical alternative for feeding ruminants. However, most pastures in Central Brazil are experiencing some degree of degradation. Crop-livestock integration has been shown to be a sustainable and viable alternative for the recovery of these degraded areas. The objective of this study was to evaluate the morphogenic and structural characteristics of Paiaguas palisadegrass and to determine the population dynamics and the survival rate of the tillers, through a stability diagram of the grass, after intercropping with sorghum for the recovery of pastures in different, integrated, crop-livestock forage systems. The experimental design was a randomized block design, with four replications. The treatments were composed of four forage systems: Paiaguas palisadegrass monoculture, sorghum intercropped with Paiaguas palisadegrass in the row, sorghum intercropped with Paiaguas palisadegrass in the interrow, and sorghum intercropped with oversown Paiaguas palisadegrass. The evaluations were performed in the four climatic seasons of the year (winter, spring, summer, and fall) in the same plots during the period of one year in 161042 $\mathrm{m}^{2}$ enclosures under a continuous stocking system. No effect was observed for the forage systems and seasons of the year on the leaf elongation rate, leaf senescence rate, and leaf life span. The development of Paiaguas palisadegrass was reduced in the winter relative to the other seasons of the year. However, it presented satisfactory production during this period despite the low rainfall. The results showed that the Paiaguas palisadegrass showed satisfactory production in all forage systems and may be indicated for intercropping with sorghum to promote the recovery and formation of pastures. The use of crop-livestock integration systems is an efficient cultivation technique for the recovery and formation of low-cost pastures to meet the demands of animal production.
\end{abstract}

KEYWORDS: Urochloa brizantha. Tiller. Forage mass. Intensive grazing.

\section{INTRODUCTION}

Pasture degradation is the largest problem facing the production of Brazilian livestock. According to a Lapig (2018) survey, of the 180.890.097 ha of pasture land in Brazil, 63.745.727 ha shows signs of degradation. This situation generates concern for cattle ranchers because pastures are the basis of the bovine herd diet due to the low production cost, high productive potential, and good adaptation of pastures to the different Brazilian ecosystems (COSTA et al., 2010; QUARESMA et al., 2011).

The system of crop-livestock integration has contributed to reductions in degraded areas and promoted pasture recovery, in addition to diversifying areas that are currently planted with Marandu palisadegrass (COSTA et al., 2016).
This technique is notable because it is a sustainable and competitive technology for leveraging agribusiness. Sowing of grazing forage intercropped with annual crops has been shown to be efficient and economically viable as a method of pasture recovery and renewal. After the crop is harvested, the pasture is established mainly for use during the dry season, when low forage production occurs (ALMEIDA et al., 2012).

Among the forages used in integrated systems, Urochloa syn. (Brachiaria brizantha cv. BRS Paiaguas) stands out because it meets the requirements of different production systems with different technological levels, and it shows satisfactory forage production during periods of low rainfall or dry seasons (COSTA et al., 2016; SANTOS et al., 2016). 
However, little is known about the management of Paiaguas palisadegrass after the annual crop has been harvested. Therefore, the qualitative and quantitative characteristics are far below the potential of the tropical forages, making the development of studies that aim at the improvement of pasture management techniques pertinent for rationalizing the use and maximizing the potential of the grasses. All this potential can be converted into animal gain, maximizing the costbenefit ratio of a production system (HOFFMANN et al., 2014).

Because they have direct action on the productive characteristics of the pastures, the morphogenic variables are of paramount importance for the correct management of these areas. Morphogenesis can be described by three basic characteristics: appearance, elongation, and leaf life span. Despite being genetically determined, these characteristics can be influenced by environmental variables, such as temperature, light intensity, water availability, nutrients, and grazing effects, which define the rates and duration of the processes (CASAGRANDE et al., 2010).

As with morphogenic variables, knowledge of the structural characteristics of the pasture, such as the population density of the tillers, the number of leaves per tiller, and the leaf:stem ratio, allows greater reliability in the results already being obtained with tropical grasses because the same characteristics determine the total mass available to the animal. The production of mass per tiller is dependent on the rates of leaf appearance and elongation, as well as on the life span of the leaf. However, the yield per area and the structure of the pasture is dependent on the density of the tillers (CAMINHA et al., 2010).

While taking into consideration the above and the importance of pasture management and while seeking to contribute to sustainability and achieve high yield, the present study aimed to evaluate the morphogenic and structural characteristics and to determine the population dynamics and the survival rate of the tillers through a diagram of stability for Paiaguas palisadegrass after sorghum intercropping for pasture recovery in different forage systems with crop-livestock integration.

\section{MATERIAL AND METHODS}

\section{Characterization of the area and treatments}

The experiment was conducted in the cattle sector of the Goiano Federal Institute, Rio Verde Campus, at $748 \mathrm{~m}$ altitude, $17^{\circ} 48^{\prime} \mathrm{S}$ and $50^{\circ} 55^{\prime} \mathrm{W}$.
The area used was Urochloa syn. (Brachiaria brizantha $\mathrm{cv}$. Marandu) pasture, implemented more than 40 years ago and in an advanced stage of degradation.

Soil samples were collected (Dystrophic Red Latosol) (Embrapa, 2013) to determine the physicochemical characteristics of the $0-20 \mathrm{~cm}$ layer of the soil in the experimental area before the forage systems were implemented, with the following results: clay: $500 \mathrm{~g} \mathrm{~kg}^{-1}$; silt: $220 \mathrm{~g} \mathrm{~kg}^{-1}$; sand: $280 \mathrm{~g}$ $\mathrm{kg}^{-1} ; \mathrm{pH}$ in $\mathrm{CaCl}_{2}$ : 5.51; $\mathrm{Ca}: 2.20 ; \mathrm{Mg}: 0.91 ; \mathrm{Al}$ : $0.01 ; \mathrm{Al}+\mathrm{H}: 3.30 ; \mathrm{K}_{2} \mathrm{O}: 0.09 ; \mathrm{CEC}: 6.51 \mathrm{cmol}_{\mathrm{c}} \mathrm{dm}^{-}$ 3; and P (Mehlich): 0.34; Cu: 2.2; Zn: 0.4; Fe: 14.4 in $\mathrm{mg} \mathrm{dm}^{-3}$; and MO: $28.70 \mathrm{~g} \mathrm{~kg}^{-1}$.

The preparation of the area began with the desiccation of the previous crop by an application of the herbicide glyphosate at $2.058 \mathrm{~g}$ a.i. ha ${ }^{1}$ with a broth volume of $150 \mathrm{~L}$ ha. Thirty days after crop desiccation, disking was performed with a disk harrow, followed by leveling with a disk.

The experimental design was a randomized complete block design with four replications. The treatments were composed of the following forage systems: Paiaguas palisadegrass in monoculture, sorghum intercropped with Paiaguas palisadegrass in the row, sorghum intercropped with Paiaguas palisadegrass in the interrow, and sorghum intercropped with oversown Paiaguas palisadegrass. The evaluations were carried out in the four climatic seasons of the year (winter, spring, summer, and fall) in the same plots, over a period of one year, from July 2015 to August 2016.

\section{Implementation and maintenance of forage systems}

The area of each plot was $1042 \mathrm{~m}^{2}$, divided into 16 enclosures with electric fence. The sorghum used was the Buster hybrid of red grain, without tannin and of low size, and the Urochloa species was BRS cv. Paiaguas.

The planting of the forage systems was performed mechanically on January 24, 2015, with the application of $240 \mathrm{~kg} \mathrm{ha}^{-1}$ of $\mathrm{P}_{2} \mathrm{O}_{5}$ and $20 \mathrm{~kg} \mathrm{ha}^{-1}$ of FTE BR 20, in the sources of simple superphosphate and frits, respectively.

In monoculture and intercropping, the sorghum was sown at a depth of $3 \mathrm{~cm}$. In the Paiaguas palisadegrass monoculture, the grass was sown at a depth of $3 \mathrm{~cm}$; in the row, it was sown at a depth of $6 \mathrm{~cm}$; in the interrow, it was sown at a depth of $3 \mathrm{~cm}$ and $0.25 \mathrm{~m}$ from the sorghum row; and in the oversown treatment, it was sown at a depth of $6 \mathrm{~cm}$ and $0.25 \mathrm{~m}$ from the sorghum row, 15 days after the sorghum had been sown. 
Morphogenesis, structure...

At 15 DAS (days after sowing), $80 \mathrm{~kg} \mathrm{ha}^{-1}$ of nitrogen and $40 \mathrm{~kg} \mathrm{ha}^{-1}$ of $\mathrm{K}_{2} \mathrm{O}$, in the form of urea and potassium chloride, were applied. On $05 / 04 / 2015$, all forage systems were harvested for silage by a row forage harvester at $20 \mathrm{~cm}$ height above the soil.

After the plants were harvested from the forage systems, cover fertilization was conducted in all systems, with the application of $80 \mathrm{~kg} \mathrm{ha}^{-1}$ of nitrogen and $30 \mathrm{~kg} \mathrm{ha}^{-1}$ of $\mathrm{K}_{2} \mathrm{O}$. The Paiaguas palisadegrass remained at rest for 94 days to allow regrowth and development. The long rest period was due to the low precipitation obtained during this period, which limited development of the grass.

On $08 / 25 / 2015$, the animals entered the area for evaluation of animal performance and forage production. The grazing method was continuous stocking, with a variable stocking rate.

The animals used were of the Nelore breed and included 32 females, with a mean age of 12
SILVA, J. T. et al.

months (heifers) and mean initial weight of $180 \mathrm{~kg}$. Evaluations were performed over a year, for all seasons of the year, with winter being the first season evaluated. During this period, eight cuts were performed: two cuts per season, with a 28-day interval and eight grazing cycles.

All animals received water and a complete mineral mixture ad libitum in the area of each enclosure, in addition to sanitary management (vaccination and deworming).

Due to the low availability of forage, in December 2015, $80 \mathrm{~kg} \mathrm{ha}^{-1}$ nitrogen and $50 \mathrm{~kg} \mathrm{ha}^{-1}$ of $\mathrm{K}_{2} \mathrm{O}$ were applied in the form of urea and potassium chloride. After fertilization, the Paiaguas palisadegrass was not grazed for 28 days for better forage development.

Over the course of the experiment, rainfall and mean monthly temperature data were monitored daily (Figure 1).

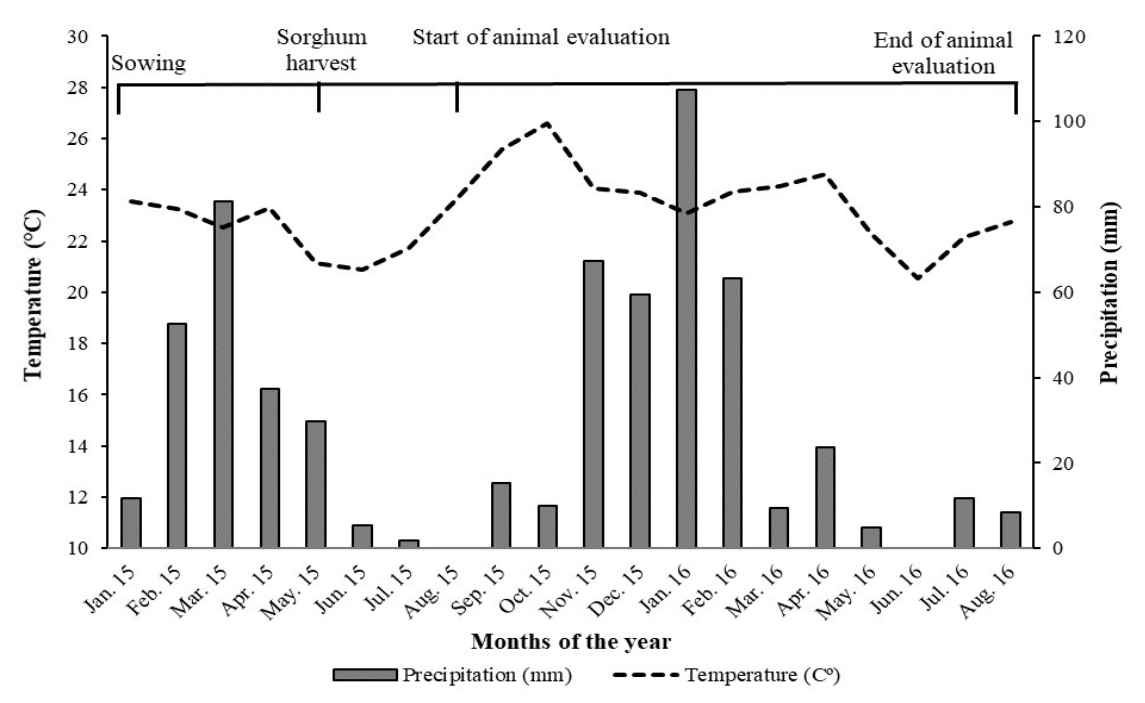

Figure 1. Rainfall (mm) and mean temperature $\left({ }^{\circ} \mathrm{C}\right)$ in Rio Verde, Goiás, Brazil, from January 2015 to August 2016.

\section{Evaluation of forage production}

The evaluations of the canopy height in the enclosures were accomplished by measuring 25 points in each experimental unit with the aid of a ruler with centimeter graduations. Samples were collected from Paiaguas palisadegrass at medium height, according to the grazing cycle of the animals, every 28 days in each enclosure at $20 \mathrm{~cm}$ above the ground to evaluate the dry matter production and the leaf:stem ratio.

The morphological composition and yield of the Paiaguas palisadegrass were determined by leaf dry mass (LDM), stem dry mass (SDM), dry mass of dead material (DMDM), green dry mass
(GDM), total dry mass (TDM), leaf blade:stem ratio (LB:S), and forage accumulation rate (FAR).

The forage mass (dry green mass - GDM and total dry mass - TDM) was quantified by means of two samplings per $0.50 \times 0.50 \mathrm{~m}\left(0.25 \mathrm{~m}^{2}\right)$ square enclosures, arranged between rows, by cutting the forage contained inside the square at $20 \mathrm{~cm}$ above the soil, with those values expressed in $\mathrm{kg} \mathrm{ha}^{-1}$. The samples were separated; fractionated into the leaf, pseudostem (stem + sheath), and dead material; and dried in a forced circulation oven at $55^{\circ} \mathrm{C}$ for 72 hours. In each sample, the number of tillers was counted to determine the density of the tillers (tillers $/ \mathrm{m}^{2}$ ). 
The forage accumulation rate $\left(\mathrm{kg} \mathrm{ha}^{-1}\right)$ was determined by using two exclusion cages per enclosure. Every 28 days, the cages were placed in points representative of the mean enclosure height, with mass and morphological composition similar to the grazing areas. After each cut, made close to the ground and inside each cage, the exclusion cages were relocated in the enclosures. The forage accumulation rate was obtained by means of the difference between the forage masses collected inside (current cut) and outside (previous cut) of the cages, considering only the green portion of the plant.

For evaluations of the morphogenic characteristics, five tillers per experimental unit were marked throughout the experimental period. Each tiller was marked with colored rings, and the position was marked with the use of iron rebar to facilitate localization. In each data collection cycle, a new tiller group was selected for evaluation.

From the data recorded in the field, the following calculations were performed to determine the response variables:

- leaf appearance rate (LApR) in leaf/tiller/day: the quotient between the number of leaves per tiller in the evaluated period and number of days in the period.

- phyllochron in days: inverse of leaf appearance rate (days/leaf/tiller);

- foliar elongation rate (LElR) in $\mathrm{cm} /$ tiller/day: mean length variation of the leaf in expansion during the evaluation period.

- leaf senescence rate (LSR), in cm/tiller/day: mean variation in the length of the senescent portion of the leaf, and the result of the product between the length of the senescent leaf blade and the proportion of corresponding senescent tissue observed throughout the evaluation period.

- number of live leaves (NLL): count of the number of non-senescent live leaves.

- pseudostem elongation rate (SElR), in $\mathrm{cm} /$ tiller/day: mean variation of the pseudostem length during the evaluation period.

For the evaluation of the population dynamics of the tillers, two PVC rings $(20 \mathrm{~cm}$ in diameter) per experimental unit were used. The first tiller marking was performed after grazing, with all tillers being marked with a color and called zero generation (G0). In the following month, the existing tillers in the rings from G0 were counted (only the live ones), and the new ones marked with a different color. These tillers were then named as 1st generation (G1) and so on in each month of evaluation. Thus, the tillers belonging to all generations evaluated were always recounted with each new evaluation, and the new tillers were marked with a new color, giving rise to a new generation. The mean interval between evaluations was 28 days.

\section{Statistical analysis}

The variables were submitted to the analysis of variance, through the $\mathrm{R}$ program version R-3.1.1 (2014), using the ExpDes package (FERREIRA et $a l ., 2014)$. The means were compared by the Tukey test at $5 \%$ probability. For the evaluation of the forage in the different seasons of the year, the analyses were carried out by the repeated measures in time model.

\section{RESULTS}

No effect was observed for the forage systems $(p>0.05)$ on the leaf dry mass, stem dry mass, and dry mass of the dead material (Table 1). However, a significant difference $(p<0.05)$ was observed for the seasons, where the highest value observed for the leaf dry mass was in the summer and the lowest in the winter.

For stem dry mass, the highest value was obtained in the spring and the lowest in the winter, followed by autumn and summer (Table 1). However, during winter, the dry mass of the dead material was also statistically $(\mathrm{p}<0.05)$ higher.

According to Table 2, values of the green dry mass, total dry mass, and leaf blade:stem ratio of the Paiaguas palisadegrass followed the same behavior of the variables mentioned previously (Table 1); that is, no effect ( $>0.05)$ was observed of the forage system on these variables. However, a significant effect $(\mathrm{p}<0.05)$ of the seasons of the year on the variables was observed.

For the dry green mass and total dry mass, the same behavior was observed, where the values of these variables were higher during spring $(p<0.05)$. The leaf blade:stem ratio was higher during the summer; however, no significant difference $(p>0.05)$ was observed for this ratio during the other seasons (Table 2).

Among the morphogenic and structural characteristics, no influence $(\mathrm{p}>0.05)$ of the forage system was observed for the variables of final leaf size, leaf appearance rate, and leaf elongation rate (Table 3). For the seasons of the year, a significant difference $(p<0.05)$ was observed in the final leaf size and leaf appearance rate, with a decrease in the values of these variables during the seasons. 
Morphogenesis, structure...

SILVA, J. T. et al.

Table 1. Leaf dry mass (LDM), stem dry mass (SDM), and dry mass of dead material (DMDM) of Paiaguas palisadegrass after intercropping with sorghum in different forage systems and seasons.

\begin{tabular}{|c|c|c|c|}
\hline Forage systems & LDM & $\begin{array}{c}\text { SDM } \\
\mathrm{kg} \mathrm{ha}^{-1}\end{array}$ & DMDM \\
\hline Paiaguas in monoculture & 1235.43 & 2078.75 & 1481.06 \\
\hline Sorghum $x$ Paiaguas in the interrow & 1145.15 & 1741.18 & 1687.40 \\
\hline Sorghum $x$ Paiaguas in the row & 1142.03 & 1602.59 & 1442.93 \\
\hline Sorghum x Paiaguas oversown & 941.90 & 1729.75 & 1564.43 \\
\hline $\mathrm{P}$ value & 0.367 & 0.097 & 0.200 \\
\hline \multicolumn{4}{|l|}{ Seasons } \\
\hline Spring & $1177.59 \mathrm{~b}$ & $3429.46 \mathrm{a}$ & $2368.03 \mathrm{a}$ \\
\hline Summer & $1551.18 \mathrm{a}$ & $1210.40 \mathrm{~b}$ & $1096.06 \mathrm{~b}$ \\
\hline Fall & 947.12 bc & $1221.21 \mathrm{~b}$ & $841.31 \mathrm{~b}$ \\
\hline Winter & $788.62 \mathrm{c}$ & $1291.18 \mathrm{~b}$ & $1870.43 \mathrm{a}$ \\
\hline $\mathrm{P}$ value & $<0.001$ & $<0.001$ & $<0.001$ \\
\hline
\end{tabular}

Means followed by the same lowercase letter in the column do not differ from each other by the Tukey test at $5 \%$ probability.

Table 2. Green dry matter (GDM), total dry mass (TDM), and leaf blade: stem ratio (LB:S) of Paiaguas palisadegrass after intercropping with sorghum in different forage systems and seasons.

\begin{tabular}{lccc}
\hline Forage systems & MVS & $\begin{array}{c}\text { MST } \\
\mathbf{k g ~ h a}^{-1}\end{array}$ & LF:C \\
\hline Paiaguas in monoculture & 3314.09 & 4795.18 & 0.72 \\
Sorghum x Paiaguas in the interrow & 2886.31 & 4573.78 & 0.72 \\
Sorghum x Paiaguas in the row & 2744.68 & 4187.59 & 0.86 \\
Sorghum x Paiaguas oversown & 2671.65 & 4236.25 & 0.80 \\
P value & 0.255 & 0.325 & 0.144 \\
\hline Seasons & & & \\
Spring & $4980.56 \mathrm{a}$ & $7348.81 \mathrm{a}$ & $0.58 \mathrm{~b}$ \\
Summer & $2388.03 \mathrm{~b}$ & $3484.09 \mathrm{~b}$ & $1.25 \mathrm{a}$ \\
Fall & $2168.28 \mathrm{~b}$ & $3009.53 \mathrm{~b}$ & $0.66 \mathrm{~b}$ \\
Winter & $2079.87 \mathrm{~b}$ & $3950.37 \mathrm{~b}$ & $0.62 \mathrm{~b}$ \\
P value & $<0.001$ & $<0.001$ & $<0.001$ \\
\hline
\end{tabular}

Means followed by the same lowercase letter in the column do not differ from each other by the Tukey test at $5 \%$ probability.

Table 3. Final leaf size (FLS), leaf appearance rate (LApR), and leaf elongation rate (LElR) of Paiaguas palisadegrass after intercropping with sorghum in different forage systems and seasons.

\begin{tabular}{lccc}
\hline Forage systems & $\begin{array}{c}\text { FLS } \\
\text { (cm) }\end{array}$ & $\begin{array}{c}\text { LApR } \\
\text { (cm/ tillers days) }\end{array}$ & $\begin{array}{c}\text { LEIR } \\
\text { (cm/ tillers days) }\end{array}$ \\
\hline Paiaguas in monoculture & 6.458 & 0.130 & 0.948 \\
Sorghum x Paiaguas in the interrow & 7.070 & 0.115 & 1.113 \\
Sorghum x Paiaguas in the row & 6.960 & 0.123 & 0.914 \\
Sorghum x Paiaguas oversown & 6.174 & 0.127 & 0.827 \\
Pvalor & 0.107 & 0.723 & 0.469 \\
\hline Seasons & & & \\
Spring & $8.012 \mathrm{a}$ & $0.175 \mathrm{a}$ & 1.400 \\
Summer & $6.994 \mathrm{ab}$ & $0.145 \mathrm{a}$ & 1.053 \\
Fall & $6.281 \mathrm{~b}$ & $0.109 \mathrm{~b}$ & 0.980 \\
Winter & $5.374 \mathrm{c}$ & $0.065 \mathrm{c}$ & 0.370 \\
P value & $<0.001$ & $<0.001$ & $<0.001$ \\
\hline
\end{tabular}

Means followed by the same lowercase letter in the column do not differ from each other by the Tukey test at $5 \%$ probability. 
Among the morphogenic and structural characteristics, no influence $(\mathrm{p}>0.05)$ of the forage system was observed for the variables of final leaf size, leaf appearance rate, and leaf elongation rate (Table 3). For the seasons of the year, a significant difference $(p<0.05)$ was observed in the final leaf size and leaf appearance rate, with a decrease in the values of these variables during the seasons.

For the leaf senescence rate and leaf life span, no significant effects $(\mathrm{P}>0.05)$ were observed among the forage systems and seasons (Table 4).
However, the forage systems did not influence the stem elongation rate and number of live leaves $(\mathrm{P}>0.05)$. However, for the seasons of the year, a significant effect $(\mathrm{P}<0.05)$ was observed, where the highest value for stem elongation rate was obtained in summer, and a lower rate was observed in winter. For the variable number of live leaves, the highest values were obtained during the spring and fall (Table 4).

Table 4. Leaf senescence rate (LSR), leaf life span (LLS), stem elongation rate (SEIR), and number of live leaves (NLL) of the Paiaguas palisadegrass after intercropping with sorghum in different forage systems and seasons of the year.

\begin{tabular}{lcccc}
\hline Forage systems & $\begin{array}{c}\text { LSR } \\
\text { (cm/ tillers days) }\end{array}$ & LLS (days) & $\begin{array}{c}\text { SEIR } \\
\text { (cm) }\end{array}$ & $\begin{array}{c}\text { NLL } \\
\text { (n. leaves) }\end{array}$ \\
\hline Paiaguas in monoculture & 0.237 & 21.271 & 0.294 & 2.687 \\
Sorghum x Paiaguas in the interrow & 0.222 & 20.898 & 0.304 & 2.650 \\
Sorghum x Paiaguas in the row & 0.163 & 23.219 & 0.272 & 2.756 \\
Sorghum x Paiaguas oversown & 0.147 & 19.168 & 0.243 & 2.418 \\
P value & 0.344 & 0.628 & 0.632 & 0.823 \\
\hline Seasons & & & & \\
Spring & 0.185 & 20.938 & $0.305 \mathrm{a}$ & $3.518 \mathrm{a}$ \\
Summer & 0.219 & 20.916 & $0.393 \mathrm{a}$ & $2.287 \mathrm{~b}$ \\
Fall & 0.158 & 18.847 & $0.269 \mathrm{~b}$ & $2.775 \mathrm{~b}$ \\
Winter & 0.207 & 23.854 & $0.145 \mathrm{c}$ & $1.931 \mathrm{c}$ \\
P value & 0.422 & 0.448 & $<0.001$ & 0.003 \\
\hline
\end{tabular}

Means followed by the same lowercase letter in the column do not differ from each other by the Tukey test at $5 \%$ probability.

An interaction was observed between the forage systems and seasons of the year for the phyllochron (Table 5), with the difference significant $(p<0.05)$ for the winter period, which obtained the highest value for the intercropping in the oversown treatment $(14,020$ leaves/day/tiller) and row (13,087 leaves/day/tiller), followed by the
Paiaguas palisadegrass in monoculture $(1,003$ leaves/day/tiller) and the lowest for the intercropping in the interrow $(9,876$ leaves/day/tiller). Among the seasons, no significant effect $(p>0.05)$ was observed, but the highest value was in the winter period (11,003 leaves/day/tiller).

Table 5. Phyllochron (leaves/day/tiller) of the Paiaguas palisadegrass after intercropping with sorghum indifferent forage systems.

\begin{tabular}{lcccc}
\hline Forage systems & \multicolumn{2}{c}{ Seasons } & Fall & Winter \\
\hline Paiaguas in monoculture & Spring & Summer & 7.142 & $11.003 \mathrm{~b}$ \\
Sorghum x Paiaguas in the interrow & 5.303 & 9.663 & 6.982 & $9.876 \mathrm{c}$ \\
Sorghum x Paiaguas in the row & 6.465 & 9.596 & 7.122 & $13.087 \mathrm{a}$ \\
Sorghum x Paiaguas oversown & 5.675 & 8.731 & 6.847 & $14.020 \mathrm{a}$ \\
P value & 0.741 & 0.596 & 0.992 & 0.008 \\
\hline
\end{tabular}

Means followed by the same lowercase letter in the column do not differ from each other by the Tukey test at $5 \%$ probability.

Among the variables of tillering dynamics, the tiller appearance rates, tiller survival rate, tiller mortality rate, and tiller population density were not influenced ( $p>0.05)$ by the different forage systems. However, for the seasons, a significant effect $(p<0.05)$ was observed (Table 6).
The tiller appearance rate presented the highest values in summer and fall. The tiller survival rate was higher in the spring and summer. The tiller mortality rate was higher in the winter, followed by fall. The population density of tillers was higher in the fall and summer (Table 6). 
Morphogenesis, structure...

SILVA, J. T. et al.

Table 6. Tiller appearance rate (TAR), tiller survival rate (TSuR), tiller mortality rate (TMoR) and tiller population density (TPR) of Paiaguas palisadegrass after intercropping with sorghum in different forage systems and different seasons of the year.

\begin{tabular}{lcccc}
\hline Forage systems & TAR & TSuR & TMoR & TPR (tiller/m $\mathbf{m}^{\mathbf{2}}$ \\
\hline Paiaguas in monoculture & 45.72 & 37.17 & 62.82 & 1452 \\
Sorghum x Paiaguas in the interrow & 34.45 & 40.63 & 59.37 & 1877 \\
Sorghum x Paiaguas in the row & 44.7 & 37.82 & 62.18 & 1804 \\
Sorghum x Paiaguas oversown & 33.95 & 34.61 & 65.39 & 1924 \\
P value & 0.354 & 0.738 & 0.739 & 0.421 \\
\hline Seasons & & & & \\
Spring & $26.11 \mathrm{~b}$ & $52.52 \mathrm{a}$ & $47.48 \mathrm{c}$ & $1554 \mathrm{~b}$ \\
Summer & $52.72 \mathrm{a}$ & $44.43 \mathrm{ab}$ & $55.57 \mathrm{bc}$ & $1886 \mathrm{ab}$ \\
Fall & $51.56 \mathrm{a}$ & $28.97 \mathrm{~b}$ & $71.02 \mathrm{ab}$ & $2717 \mathrm{a}$ \\
Winter & $15.43 \mathrm{~b}$ & $17.44 \mathrm{c}$ & $82.56 \mathrm{a}$ & $779 \mathrm{c}$ \\
P value & $<0.001$ & $<0.001$ & $<0.001$ & $<0.001$ \\
\hline
\end{tabular}

Means followed by the same lowercase letter in the column do not differ from each other by the Tukey test at $5 \%$ probability.

\section{DISCUSSION}

There were no differences among forage systems for the leaf dry mass, stem dry mass, dry mass of dead material, green dry mass, total dry mass, leaf blade:stem ratio, final leaf size, leaf appearance rate, leaf elongation rate, leaf senescence rate, leaf life span, stem elongation rate, number of live leaves, tiller appearance rate, tiller survival rate, tiller mortality rate, and population density of tillers, wich showed that the Paiaguas palisadegrass can be intercropped with sorghum in different sowing ways without harming the development of the forage.

Therefore, the importance of the use of crop-livestock integration for the recovery and formation of pasture can be observed; that is, after the annual crop is harvested, the pasture can be developed for use in the dry season of the year, when a low availability of forage would typically be found due to the seasonality of forage production.

The highest leaf dry mass yield (Table 1) was observed during the summer, when the highest final leaf size and leaf appearance rate (Table 3) occurred due to the higher amount of precipitation during this period (Figure 1), which favored the development of the forage.

Because the Paiaguas palisadegrass is a tropical grass, it presents a greater yield of leaf dry mass in the months of greater rainfall and higher temperature, which increases its yield of leaf blades (COSTA et al., 2016; EPIFANIO et al., 2019).

Relative to the stem dry mass, the higher yield in the spring is due to the low rainfall, resulting in a higher production of stems and consequently lower leaf production, also proven by the leaf blade:stem ratio (Table 2). According to
Lemos et al. (2014), tropical grasses decrease the production of leaf blades and increase stem elongation due to the low availability of water.

On the other hand, the lowest values of stem dry mass during summer, fall, and winter are due to high temperature and higher amount of rainfall, which contribute to a higher leaf blade:stem ratio in these seasons. However, in the same period, the animal stocking rate was high (SANTOS, 2017), that is, control of the stem growth was achieved by grazing animals, which favors the structural components of the pasture.

The control of the stem through grazing is an efficient method to guarantee a good canopy structure and prevent the loss of material and accumulation of dead leaves (ANJOS et al., 2016; GOMIDE et al., 2009).

The higher values of dry mass of dead material and stem dry mass obtained in the spring (Table 1) can be explained by the leaf senescence rate and leaf life span (Table 4), although these variables were not significant between the treatments. This finding may have occurred due to the high animal load throughout the experimental period $\left(7.9,9.3,10.1\right.$, and 9.2 $\mathrm{UA} \mathrm{ha}^{-1}$ for the spring, summer, fall and winter, respectively), resulting in excessive pasture, thus incurring excessive defoliation and reduction of leaf area. In addition, these results may be associated with climatic conditions (SANTOS et al., 2016; CASAGRANDE et al., 2011) such as lower temperature and rainfall in the spring (Figure 1).

The highest green dry mass values in spring (Table 2) may be correlated with the final leaf size, leaf appearance rate, and number of live leaves. This fact can also be explained by the higher dry mass of the stem in the same period (Table 1). This result is 
associated with grazing because more stem occurs in the pasture due to the consumption of the leaves by the animals.

The difference found between spring and summer was $64.7 \%$ for stem dry matter, while the difference in the leaf dry mass was $24.1 \%$, providing evidence of the higher proportion of stems compared to green dry mass. This behavior by the grass can be explained by the low rainfall (Figure 1) and the time of entry of the animals into the enclosures. After harvesting the sorghum, the area was closed for 94 days until the addition of the animals. During this period, the grass was in free growth, which may be explained by the higher amount of stem in the increased green dry mass.

The highest values of stem dry mass and dry mass of dead material (Table 1) contributed to the observed result for total dry mass in the spring period. The pasture closing period (interval between the harvest of the plants of the sorghum forage systems and the addition of the animals) has a direct impact on the proportions of stem and dead material in some circumstances. This characteristic may have a prolonged effect throughout the spring, which may impair the animals' intake of dry matter.

Even during the dry period, the forage availability was satisfactory, especially in the spring, which obtained the highest total dry mass yield, demonstrating the potential of the Paiaguas palisadegrass to produce forage, even with low rainfall and while maintaining a high stocking rate.

Evaluating the dry mass production of Paiaguas palisadegrass after intercropping with millet, Costa et al. (2016) verified production of dry mass of 4,910;4,822; and 3,675 $\mathrm{g} \mathrm{ha}^{-1}$ for forage systems in the row, interrow, and oversown treatments, respectively. These results were close to those obtained in this study, which obtained a mean yield of forage systems of $4,448 \mathrm{~kg} \mathrm{ha}^{-1}$.

The highest proportion of leaves, based on the leaf blade:stem ratio during the summer, is explained by the greater amount of dry mass of leaf produced during the same period as well as the lower values for the dry mass of the stem. The rainfall that occurred during the summer months (Figure 1) favored the highest leaf yield in relation to the stem (Table 1).

Evaluating the weight gain of steers and the yield of Paiaguas palisadegrass and Piata palisadegrass, Euclides et al. (2016), verified values of leaf blade: stem ratio of 1.48 , a result close to that observed in the present study.

Studying the structural and productive attributes of Marandu palisadegrass in response to supplemented cattle and grazing cycles, Gomide et al. (2009) found leaf dry mass values between 654 and 2,225 kg DM ha ${ }^{-1}$ and leaf blade: stem ratios from 0.72 to 0.33 , and these values were lower than those obtained in this work. This difference may be due to the morphological characteristics of the forages, with the Paiaguas palisadegrass producing more DM and a greater leaf blade: stem ratio (COSTA et al., 2016; SANTOS et al., 2016).

The values of final leaf size and leaf elongation rate as a function of the different forage systems, although not significant, showed a numerical increase, which may be related to light competition. When the Paiaguas palisadegrass was sown in the oversown treatment, the values were lower due to the shading provided by the sorghum crop. Both variables (Table 3 ) during the spring and summer months were higher due to favorable climatic conditions, such as rainfall and temperature (Figure 1), favoring the development of the plants.

Thus, the plant prioritizes the production of new leaves and consequently produces new tillers. In a study of the morphogenetic and structural characteristics of the Xaraes palisadegrass, Sousa et al. (2011) verified a final leaf size of $12.2 \mathrm{~cm}$ in summer and $9.5 \mathrm{~cm}$ in fall and a leaf elongation rate of $1.54 \mathrm{~cm} /$ tiller/day in summer and 1.13 $\mathrm{cm} /$ tiller/day in fall.

When evaluating the morphogenic and structural characteristics of Xaraes palisadegrass at different seasons of the year, Rodrigues et al. (2014) obtained higher values for the leaf appearance rate, with $0.09 \mathrm{~cm} /$ tiller/day in the rainy season and 0.07 $\mathrm{cm} /$ tiller/day in the dry season, and for leaf elongation rate, they reported $3.18 \mathrm{~cm} /$ tiller/day in the rainy season and $2.36 \mathrm{~cm} /$ tiller/day in the dry season.

Smaller heights tend to increase the concentration of auxin (plant growth hormone) and the incidence of luminosity in the basal buds, allowing the emergence of new tillers and the appearance of new consecutive leaves and, consequently, increasing the rate of appearance of leaves (RODRIGUES et al., 2014), which occurred in the present study (Table 3 ).

Studying the morphogenic characteristics of Marandu palisadegrass in new and old tillers, Paiva et al. (2011) observed a leaf appearance rate of $0.097 \mathrm{~cm} /$ tiller/day for young tillers and 0.048 $\mathrm{cm} /$ tiller/day for old tillers, with the leaf appearance rate being correlated with the final leaf size.

The rate of leaf appearance is largely determined by two factors: the leaf elongation rate and the length of the sheath through which the leaf travels to emerge. Thus, any changes in one of these factors directly influence the rate of leaf appearance 
(SALES et al., 2014). In the case of this study, the leaf elongation rate did not have as much influence, as it experienced no significant effect from the treatment.

As colder months and shorter days approached, the Paiaguas palisadegrass increased the leaf life span and decreased the leaf appearance rate. Although the leaf life span in this study did not differ for the seasons $(\mathrm{P}>0.05)$, it tended to increase from fall to winter (Table 4) due to unfavorable climatic conditions (low rainfall and temperature) (Figure 1) for the emission of new leaves.

In this case, the plant increases the life span of the leaves, thus being able to have less loss due to senescence. This process is controlled by several physiological factors that are associated with grass morphogenesis and may also be affected by management and region (ANJOS et al., 2016).

The highest stem elongation rate values, observed in the summer and spring (Table 4), are associated to the period when there is greater light availability and higher temperatures, providing better development conditions for the grass. However, during this same period, higher leaf dry mass production (Table 1) and higher leaf blade: stem ratio (Table 2) were observed, showing a higher forage yield.

For the number of live leaves, the highest values, which were observed in the spring months, are due to the effects of winter, which experienced low rainfall. Similar results were reported by Casagrande et al. (2010), who studied the morphogenetic and structural characteristics of tillers of Marandu palisadegrass under intermittent stocking and verified values for number of live leaves between 3.6 and 4.5 (leaves/tiller).

This response to the defoliation results from compensation by the plant because it allows the plant to respond quickly to changes in the defoliation system (SALES et al., 2014). This resource is activated according to the restricted lifetime of the leaf, determined by genetic characteristics and influenced by climate and management conditions. This event is important because the leaves are the portion of the plant with the highest nutritional value (PEREIRA et al., 2011).

When evaluating the morphogenic and structural characteristics of Xaraes palisadegrass, Sousa et al. (2011) observed 4.73 leaves/tiller for live leaves in the summer and 5.40 leaves/tiller in the fall. These values were higher than those obtained in this study, which was 2.28 leaves/tiller in the summer and 2.77 leaves/tiller in the fall.
Contrary to the number of live leaves, the leaf elongation rate, leaf senescence rate, and leaf life span were not significantly different among the seasons. However, a tendency existed for these values to be lower in the fall, which is explained by the low total dry mass production.

Rodrigues et al. (2014) observed values higher than those from this study when evaluating Xaraes palisadegrass in the dry and rainy season; they observed leaf senescence rate in the rainy season of $0.98(\mathrm{~cm} /$ day/tiller $)$ and in the dry season of $0.13(\mathrm{~cm} /$ day/tiller) and observed a leaf life span in the rainy season of 19.32 (days/leaf) and in the dry season of 24.11 (days/leaf).

Higher levels of residues result in higher performance of dead matter because they have a higher index of leaf area, which may lead to competition for light, thus causing the senescence process of the basal leaves of the tiller (RODRIGUES et al., 2014).

The highest values of phyllochron were observed in the winter period (Table 5), due to shorter days, which contribute to the decrease in the average temperatures, affecting the development of the plant. Phyllochron represents the time required for the appearance between two successive leaves in a tiller (PEREIRA et al., 2011).

On the other hand, the lower value of the phyllochron obtained in the system with sorghum with Paiaguas palisadegrass in the interrow, suggests this form of sowing can be beneficial for the interval of emergence for leaves during the winter. Lower phyllochron results were reported by Junior et al. (2013), who evaluated the productive, morphogenic, and structural characteristics of the piatã grass submitted to organic fertilization, and verified values ranging from 5.14 to 7.84 (days/leaf/tiller).

When studying the morphogenetic and structural characteristics of the Marandu palisadegrass managed under intermittent grazing with different forage, Casagrande et al. (2010) observed values of phyllochron from 9 to 13.6 (day/leaf/tiller), values similar to those obtained in the winter period in the present study.

For the tiller dynamics variables, the appearance, survival, and mortality rates of tillers and the population density of tillers are directly correlated with light intensity, rainfall, temperature, and nutrients, especially nitrogen. Although not significantly different between the forage systems, tiller appearance rates and tiller survival rates were numerically lower in the oversown treatment (33.95 and 34.61), with the opposite being observed for the tiller mortality rate and tiller population density, 
Morphogenesis, structure...

which were higher in this treatment, with values of 65.39 and 1924, respectively (Table 6).

The highest tillering rates and population density of tillers were obtained in summer and fall, the highest tiller survival rate was observed in the spring and summer, and the highest tiller mortality rate was observed in winter and fall (Table 6); these variables are directly correlated with the leaf appearance rate, leaf life span, and number of live leaves. This result is explained by variations in climatic conditions (Figure 1) and management (GIMENES et al., 2011).

Paiva et al. (2011), while studying the tillering of the Marandu palisadegrass, observed that from June to October, the tiller appearance rate was low and the tiller survival rate was high. Such response indicates that under such limited environmental conditions, plants resort to resource conservation strategies as a means of ensuring persistence, and these strategies are usually associated with the final leaf size and tiller lifespan (GIACOMINI et al., 2009).

Evaluating Marandu palisadegrass under rotational stock management strategies, Fialho et al. (2012) found tiller appearance rate values between 23 to 48 , tiller mortality rate between 20 to 44, and TPR between 765 to 1471 . These results are similar
SILVA, J. T. et al.

to those obtained in this study and those reported by Casagrande et al. (2010) for the population density of tillers, with values from 918 to 1742 .

\section{CONCLUSIONS}

Paiaguas palisadegrass showed satisfactory production in all forage systems and may be indicated for intercropping with sorghum to promote the recovery and formation of pastures.

The development of Paiaguas palisadegrass was reduced in the winter relative to the other seasons of the year. However, it presented satisfactory dry mass production during this period despite the low rainfall.

The use of crop-livestock integration systems is an efficient cultivation technique for the recovery and formation of low-cost pastures to meet the demands of animal production.

\section{ACKNOWLEDGEMENTS}

We acknowledge the Goiano Federal Institute for the support of this research, the National Council for Scientific and Technological Development (CNPq), and the Goias Research Foundation (FAPEG) for financing the project.

RESUMO: O uso de pastagens é a alternativa mais econômica para a alimentação de ruminantes. No entanto, a maioria das áreas de pastagens no Brasil Central, encontra-se em algum grau de degradação. Com isso, a integração lavoura-pecuária tem se mostrado como alternativa sustentável e viável para a recuperação dessas áreas. Sendo assim, objetivou-se avaliar as características morfogênicas e estruturais, determinar a dinâmica populacional e taxa de sobrevivência dos perfilhos através do diagrama de estabilidade do capimpaiaguás, após o consórcio com o sorgo, na recuperação de pastagens, em diferentes sistemas forrageiros na integração lavoura-pecuária. O delineamento experimental utilizado foi o de blocos casualizados, com quatro repetições. Os tratamentos foram constituídos de quatro sistemas forrageiros: capim-paiaguás em monocultivo; sorgo consorciado com o capim-paiaguás na linha; sorgo consorciado com o capim-paiaguás na entrelinha e sorgo consorciado com o capim-paiaguás na sobressemeadura. As avaliações foram realizadas nas quatro estações climáticas do ano (inverno, primavera, verão e outono) nas mesmas parcelas, durante o período de um ano, em 16 piquetes de $1042 \mathrm{~m}^{2}$ sob sistema de lotação contínua. Não foi observado efeito dos sistemas forrageiros e estações do ano sobre a taxa de alongamento foliar, taxa de senescência foliar e duração de vida das folhas. No período de inverno, houve redução do desenvolvimento do capim-paiaguás em relação as outras estações do ano. No entanto, apresentou desempenho satisfatório de produção, mesmo com baixa precipitação. Os resultados demostraram que o capim-paiaguás apresenta produção satisfatória em qualquer sistema forrageiro, podendo ser indicado para o consórcio com sorgo, para a recuperação e formação de pastagens. $\mathrm{O}$ sistema de integração lavoura-pecuária tem-se mostrado como técnica de cultivo eficaz para recuperação e formação de pastagens de baixo custo, para atender a demanda da produção animal.

PALAVRAS-CHAVE: Urochloa brizantha, perfilho, massa de forragem, pastejo intensivo. 


\section{REFERENCES}

ALMEIDA, C.M.; LANA, Â.M.Q.; RODRIGUES, J.A.S.; ALVARENGA, R. C.; BORGES, I. Influência do tipo de semeadura na produtividade do Consórcio sorgo - Urochloa Brizantha cv. Marandu no sistema de integração lavoura-pecuária. Revista Brasileira de Milho e Sorgo, Sete Lagoas, v.11, n.1, p. 60-68, 2012. https://doi.org/10.18512/1980-6477/rbms.v11n1p60-68

ANJOS, A.J. DOS; GOMIDE C.A. DE M.; RIBEIRO K.G.; MADEIRO A.S.; MORENZ M.J.F.; DOMINGOS SÁVIO CAMPOS PACIULLO D. S. C. Forage mass and morphological composition of Marandu palisade grass pasture under rest periods. Ciência e Agrotecnologia, Lavras, v.40 n.1, p.76-86, 2016. https://doi.org/10.1590/S1413-70542016000100007

CAMINHA, F.O.; SILVA, S.C. DA; PAIVA, A.J.; PEREIRA, L.E. T.; MESQUITA, P. DE; GUARDA, V. D. Estabilidade da população de perfilhos de capim-marandu sob lotação contínua e adubação nitrogenada. Pesquisa Agropecuária brasileira, Brasília, v.45, n.2, p.213-220, 2010. https://doi.org/10.1590/S0100204X2013000800iii

CASAGRANDE, D.R.; RUGGIERI A.C.; JANUSCKIEWICZ E.R.; GOMIDE J.A.; REIS R.A.; VALENTE A.L.D.A.S. Características morfogênicas e estruturais do capim-marandu manejado sob pastejo intermitente com diferentes ofertas de forragem. Revista Brasileira de Zootecnia, Viçosa v.39, n.10, p.2108-2115, 2010. https://doi.org/10.1590/S1516-35982010000100008

CASAGRANDE, D.R.; RUGGIERI, A.C.; BERCHIELLI, T.T.; MORETTI, M.H.; VIEIRA, B.R.; ROTH, A.P.T.P.; REIS, R.A. Sward canopy structure and performance of beef heifers under supplementation in Brachiaria brizantha cv. Marandu pastures maintained with three grazing intensities in a continuous stocking system. Revista Brasileira de Zootecnia, Viçosa, v.40, n.10, p. 2074-2082, 2011. https://doi.org/10.1590/S1516-35982011001000002

COSTA, K.A.P.; FAQUIN, V.; OLIVEIRA, I.O. Doses e fontes de nitrogênio na recuperação de pastagens do capim-marandu. Arquivo Brasileiro de Medicina Veterinária e Zootecnia, Belo Horizonte, v.62, p.192-199, 2010. https://doi.org/10.1590/S0102-09352010000100026

COSTA, R.R.G.F.; COSTA, K.A. DE P.; SANTOS, C.B.; SEVERIANO, E.DA C.; EPIFANIO, P.S.; SILVA, J.T.DA; TEIXEIRA, D.A.A.; DA SILVA, V.R. DA. Production and nutritional characteristics of pearl millet and Paiaguas palisadegrass under different forage systems and sowing periods in the offseason. African Journal of Agricultural, Ebène, v. 11, n.19, p. 1712-1723, 2016. https://doi.org/10.5897/AJAR2016.10902

EMBRAPA SOLOS - EMPRESA BRASILEIRA DE PESQUISA AGROPECUÁRIA -EMBRAPA. Centro Nacional de Pesquisa de Solos. Sistema Brasileiro de Classificação de Solos. Embrapa CNPS, 3 ed. Rio de Janeiro, 2013. 353p.

EUCLIDES, V.P.B.; MONTAGNER, D.B.; BARBOSA, R.A.; VALLE, C.B.; NANTES, N.N. Animal performance and sward characteristics of two cultivars of Brachiaria brizantha (BRS Paiaguás and BRS Piatã). Revista Brasileira de Zootecnia, Viçosa, v. 45, p. 85-92, 2016. https://doi.org/10.1590/S151635982010000100008

EPIFANIO, P.S.; COSTA, K.A.P.; SEVERIANO, E.C.; SOUZA, W.F., TEIXEIRA, D.A.A.; SILVA, J. T.; AQUINO, M. M. Productive and nutritional characteristics of Brachiaria brizantha cultivars intercropped with Stylosanthes cv. Campo Grande in different forage systems. Crop \& Pasture Science, Melbourne, v.70, p.718729, 2019. https://doi.org/10.1071/CP18447

FERREIRA, E.B.; CAVALCANTI, P.P.; NOGUEIRA, D. A. ExpDes: An R Package for ANOVA and Experimental Designs. Applied Mathematics, v.5, p.2952-2958, 2014. https://doi.org/10.4236/am.2014.519280 
FIALHO, C.A.; SILVA1, S.C. DA; GIMENES, F.M. DE A.; GOMES, M.B.; BERNDT, A.; GERDES, L. Tiller population density and tillering dynamics in marandu palisade grass subjected to strategies of rotational stocking management and nitrogen fertilization. Acta Scientiarum. Animal Sciences, Maringá, v. 34, n. 3, p. 245-251, 2012. https://doi.org/10.4025/actascianimsci.v34i3.13739

GIACOMINI, A.A.; SILVA, S.C.DA; SARMENTO, D.O.DE L.; ZEFERINO, C.V.; JÚNIOR, S.J.S.; TRINDADE, J. K. DA; GUARDA, V. D. A.G.; JÚNIOR, D. DO N. growth of marandu palisadegrass subjected to strategies of intermittent stocking. Marandu palisadegrass subjected to intermittent stocking. Scientia Agricola, Piracicaba, v.66, n.6, p.733-741, 2009. https://doi.org/10.1590/S0103-90162011000200013

GIMENES, F.M.A; SILVA, S.C; FIALHO, C.A; GOMES, M.B; BERNDT, A.; GERDES, G.; COLOZZA, MT Ganho de peso e Produtividade em animais capim-marandu soluçar pastejo rotativo e adubação nitrogenada. Pesquisa Agropecuária Brasileira, Brasília, v. 46, n. 7, p.751-759, 2011. https://doi.org/10.1590/S0100204X20130008000ii

GOMIDE, C.A.M.; REIS, R. A.; SIMILLI, F.F. Atributos estruturais e produtivos do capim-marandu em resposta à suplementação alimentar de bovinos e a ciclos de pastejo. Pesquisa Agropecuária Brasileira, Brasília, v.44, n.5, p.526-533, 2009. https://doi.org/10.1590/S0100-204X2009000500013

HOFFMANN, A.; MORAES, E. H. B. K. DE; MOUSQUER, C. J.; SIMIONI, T. A.; GOMES, F. J.; FERREIRA,V. B.; SILVA, H. M. DA. Produção de bovinos de corte no sistema de pasto-suplemento no período seco. Nativa, Sinop, v. 02, n. 02, p. 119-130, 2014. https://doi.org/10.14583/2318-7670.v02n02a10

JUNIOR, M.A.P.O.; CENTURION, S.R.; ORRICO, A.C.A.; OLIVEIRA, A.B. DE M.; SUNADA, N.DA S. Características produtivas, morfogênicas e estruturais do capim Piatã submetido à adubação orgânica. Ciência Rural, Santa Maria, v.43, n.7, p.1238-1244, 2013. https://doi.org/10.1590/S0103-84782013005000085

LAPIG, Laboratório de Processamento de Imagens e Geoprocessamento. 2018. Disponível em:

https://www.lapig.iesa.ufg.br/lapig/index.php/produtos/atlas-digital-das-pastagens-brasileiras. Acesso em: abril, 2020.

LEMOS, N L.S.; RUGGIERI, A.C.; SILVA, V.C.; CAMPOS, A.F.; MALHEIROS, E.B.; TEIXEIRA, I.A. M.A. Tanzania grass structure grazed by goats managed with different residual leaf area index under intermittent stocking. Bioscience Journal, Uberlândia, v.30, p. 1811-1818, 2014.

PAIVA, A. J.; SILVA S. C. DA; PEREIRA L. E. T.; CAMINHA F. O.; PEREIRA P. DE M.; GUARDA V. D. A. Morphogenesis on age categories of tillers in marandu palisadegrass. Scientia Agrícola, Piraciacaba v.68, n.6, p.626-631, 2011. https://doi.org/10.1590/S0103-90162011000200013

PEREIRA, V. V.; FONSECA, D. M.; MARTUSCELlO, J. A.; BRAZ, T. G. S.; SANTOS, M. V.; CECON, P. R. Características morfogênicas e estruturais de capim mombaça em três densidades de cultivo adubado com nitrogênio. Revista Brasileira de Zootecnia, Viçosa, v. 40, n. 12, p. 2681-2689, 2011.

https://doi.org/10.1590/S1516-35982010000100008

QUARESMA, J.P.S.; ALMEIDA, R.G.; ABREU, J.G.; CABRAL L.S.; OLIVEIRA, M.A.; CARVALHO, D.M.G. Produção e composição bromatológica do capim-tifton 85 (Cynodon spp.) submetido a doses de nitrogênio. Acta Scientiarum. Animal Sciences, Maringá, v. 33, n. 2, p.145-150, 2011. https://doi.org/10.4025/actascianimsci.v33i2.9261

RODRIGUES, R. C.; AMORIM, S. E. P.; MELLO, M. A. de A.; SANTOS, C. C.; SANCHÊS, S. S. C.; GALVÃO, C. M. L. Características morfogênicas e estruturais do capim-xaraés submetido a intensidades de desfolhas. Revista Brasileira de Saúde Produção Animal, Salvador, v.15, n.2, p.430-439, 2014. https://doi.org/10.1590/S1519-99402014000200002 
SALES, E. C. J. DE; REIS S. T. DOS; JÚNIOR V. R. R.; MONÇÃO F. P.; MATOS V. M.; PEREIRA D. A.; AGUIAR A. C. R. DE; ANTUNES A. P. DA S. Características morfogênicas e estruturais da Brachiaria brizantha cv. Marandu submetida a diferentes doses de nitrogênio e alturas de resíduos. Semina: Ciências Agrárias, Londrina, v. 35, n. 5, p. 2673-2684, 2014. https://doi.org/10.5433/1679-0359

SANTOS, C.B. Consórcio do sorgo granifero com capim-paiaguás na recuperação de pastagem em sistema de integração lavoura-pecuária. Rio Verde: Instituto Federal Goiano, Campus, 2017. Dissertação de Mestrado.

SANTOS, C. B.; COSTA, K. A de P.; OLIVEIRA, I. P de.; SEVERIANO, E. DA C.; COSTA, R. R. G. F.; SILVA, A. G. da.; GUARNIERI, A.; SILVA, J. T. da.; Production and nutritional characteristics of sunflowers and paiaguas palisadegrass under different forage systems in the off season. Bioscience Journal, Uberlândia, v. 32, n. 2, p. 460-470, 2016. https://doi.org/10.14393/10.14393/BJ-v32n2a2016-29753

SOUSA, B. M. DE L.; JÚNIOR D. DO N.; RODRIGUES C. S.; MONTEIRO H. C. DE F.; SILVA S. C. DA; FONSECA D. M. DA; SBRISSIA A. F. Morphogenetic and structural characteristics of xaraes palisadegrass submitted to cutting Heights. Revista Brasileira de Zootecnia, Viçosa, v.40, n.1, p.53-59, 2011. https://doi.org/10.1590/S1516-35982010000100008 